\title{
Report of Korean Association of External Quality Assessment Service on the Accuracy-Based Lipid Proficiency Testing (2016-2018)
}

Jeong-Ho Kim ${ }^{1}$, Yonggeun Cho ${ }^{1}$, Sang-Guk Lee ${ }^{1}$, and Yeo-Min Yun ${ }^{2}$

${ }^{1}$ Department of Laboratory Medicine, Yonsei University College of Medicine;

${ }^{2}$ Department of Laboratory

Medicine, Konkuk

University School of Medicine, Seoul, Korea

Corresponding author: Jeong-Ho Kim

Department of Laboratory Medicine, Severance Hospital, Yonsei University College of Medicine, 50-1 Yonsei-ro, Seodaemun-gu, Seoul 03722, Korea

Tel: $+82-2-2228-2448$

Fax: +82-2-313-0956

E-mail: jeongho@yuhs.ac
The accuracy-based lipid (ABL) proficiency testing (PT) program was started in 2016 by the Korean External Quality Assessment Service to minimize the matrix effect. We analyzed 3 years of the program. We made or purchased six kinds of commutable frozen sera based on the Clinical and Laboratory Standards Institute 37A guideline and distributed it in two rounds per year from 2016 to 2018. We obtained reference values for levels of total cholesterol (TC), high-density lipoprotein cholesterol (HDLC), low-density lipoprotein cholesterol (LDLC), total glycerides, and triglycerides in each fresh frozen pool at the reference-measurement laboratories. We evaluated the average percent bias of the participating laboratories based on the National Cholesterol Education Program (NCEP) bias limit. The number of participating laboratories evaluating TC, HDLC, LDLC, total glycerides, and triglycerides increased from 164 to 223,163 to 223,158 to 214,98 to 139 , and 61 to 82 , respectively. The average percent bias of all participating laboratories for TC, HDLC, LDLC, total glycerides, and triglycerides was $+0.14 \%,-0.54 \%,+2.9 \%,-1.08 \%$, and $-1.32 \%$, respectively. The average percent bias exceeded the NCEP bias limit only once or twice for TC, HDLC, and total glycerides but frequently for LDLC (eight out of 18 pools). The manufacturer-specific bias estimation report seemed useful for traceability. Although the average percent bias of participating laboratories for TC, HDLC, LDLC, total glycerides, and triglycerides was mostly within the bias limit provided by NCEP, cases of bias limit exceeding the NCEP bias limit occurred occasionally, especially for LDLC during the 3 years of the ABL PT program in Korea, suggesting that ABL PT can be used to keep maintaining traceability.

(J Lab Med Qual Assur 2019;41:121-129)

Key Words: Laboratory proficiency testing, Accuracy-based proficiency testing, Cholesterol, High-density lipoprotein cholesterol, Low-density lipoprotein cholesterol, Triglycerides

\section{서론}

지질(脂質)검사는 이상지혈증의 진단, 심혈관질환의 위험도 예측 및 치료효과 추적에 사용되는 중요한 검사이다. 심혈관질 환은 전 세계적으로 사망을 유발하는 중요한 원인들 중 하나이 며, 정확한 검사실 검사결과는 심혈관질환의 진단 및 치료방침 결정에 필수적이다[1]. 미국에서 연구된 자료에 따르면, 미국 질병관리본부에서 진행한 지질검사 표준화 사업을 통해 매년 최소 3억3천8백만 달러에 해당하는 경제적 효과(총 콜레스테
롤 검사 표준화로 인한 총 콜레스테롤 관리 개선 기여도를 최 소 $0.5 \%$ 로 가정하고, 이로 인한 기대수명 연장의 가치를 5 만 불로 산정함)를 거두었다고 한다[2]. 따라서 지질검사의 정확 도를 높이고자 하는 노력은 적은 비용으로도 국민 건강 향상에 큰 기여를 할 수 있다.

대한임상검사정도관리협회는 정확도기반지질검사에 대 한 신빙도사업 프로그램(accuracy-based lipids proficiency testing program)을 2016년부터 시행하였다. 정확도기반지질 검사 신빙도사업 프로그램은 기질효과(matrix effect)를 최소 
화하고 외부정도관리물질의 교환성(commutability)을 유지하 여 지질검사의 정확도 평가에 적합하다[3-5]. 미국 병리학회 (College of American Pathologists)에서는 2008년부터 이미 정확도기반지질검사를 정확도 평가를 위한 외부정도관리 프 로그램으로 시행하였다[6]. 임상검사실에서는 지질검사의 정 확도를 유지하기 위해 측정소급성이 확보된 검사시스템(장비, 칼리브레이터, 시약의 조합)을 사용하고, 주기적으로 검사의 정확도를 검증할 수 있도록 정확도기반 외부정도관리에 참여 할 필요가 있다. 크레아티닌 경우에 이미 지난 7년간의 정확도 기반 외부정도관리의 사업을 통해 오차가 줄어들고 있음을 확 인한 바 있다[7].

저자들은 대한임상검사정도관리협회에서 주관한 정확도기 반지질검사 신빙도조사사업 자료(2016-2018)를 분석하여 국 내 임상검사실과 주요 검사시스템의 지질검사 정확도 현황을 파악하고자 하였다.

\section{재료 및 방법}

기질 효과를 최소화하기 위해 Clinical Laboratory Standard Institute 37A 지침에 따라 1회당 3가지 농도의 교 환성 냉동 혈청(commutable frozen serum, CFS)을 직접 만 들거나 Solomon Park Research Laboratories (Burien, WA, USA)로부터 구매하여 사용하였다[8]. 이를 위해 세브란스병 원 및 건국대학교병원 임상시험심사위원회의 검토 및 허락을 받았다(과제번호 4-2016-0328, 4-2017-0351, KUH1200060,
KUH1200066). 이 CFS를 가지고 총 콜레스테롤, 고밀도지 단백(high-density lipoprotein, HDL) 콜레스테롤, 저밀도지 단백(low-density lipoprotein, LDL) 콜레스테롤, 중성지방 등 정확도기반지질검사 신빙도조사에 사용했으며, 2016년부 터 연 2회씩 3년간 평가하였다. 2016년 1회차, 2회차 및 2017 년 1 회차 정도관리물질은 건국대학교병원에서 제조하였고, 2017년 2회차는 세브란스병원에서, 2018년 1회차는 Solomon Park Research Laboratories에서 구매한 것을, 2018년 2회 차는 분당서울대병원에서 제조한 것을 사용하였다. 총 콜레 스테롤, $\mathrm{HDL}$ 콜레스테롤, $\mathrm{LDL}$ 콜레스테롤 및 중성지방 등 의 참고값(reference value) 또는 목표값(target value)은 참 고측정방법을 사용하는 참고측정검사실로서 Table 1과 같 이 각 종목별로 국제적으로 인정받는 검사실에 의뢰하였다. 즉 총 콜레스테롤, $\mathrm{HDL}$ 콜레스테롤, $\mathrm{LDL}$ 콜레스테롤의 경 우에는 미국 질병관리본부에 본부를 둔 콜레스테롤 표준검 사 네트워크검사실(Cholesterol Reference Measurement Laboratory Network, CRMLN)인 캐나나 CEQAL 또는 미 국 Northwest Lipid Metabolism and Diabetes Research Laboratories에 의뢰하여 미국 Centers for Disease Control and Prevention 표준검사법인 Abell Kendall법 및 베타정량 법(beta-quantification법)으로 측정하였다[9]. 중성지방 및 유리글리세롤의 경우에는 일본의 사단법인 검사의학표준물질 기구(Reference Material Institute for Clinical Chemistry Standards)와 CRMLN 인증을 받은 우리나라 질병관리본부 만성질환예방과 국가진단의학표준검사실(National Medical

Table 1. List of reference-measurement laboratories and acceptable limits of accuracy-based lipid assays

\begin{tabular}{|c|c|c|c|}
\hline Test item & Reference measurement laboratories & Acceptable limits & $\begin{array}{c}\text { NCEP performance } \\
\text { criteria for } \\
\text { inaccuracy }[10]\end{array}$ \\
\hline High-density lipoprotein cholesterol & CEQAL, NWRL & $\pm 13 \%$ & $\pm 5 \%$ \\
\hline Low-density lipoprotein cholesterol & CEQAL, NWRL & $\pm 12 \%$ & $\pm 4 \%$ \\
\hline Apolipoprotein A1 & -9 & $\pm 15 \%$ & - \\
\hline Apolipoprotein B & -9 & $\pm 15 \%$ & - \\
\hline Lipoprotein (a) & -9 & $\pm 3 \mathrm{SD}$ & - \\
\hline
\end{tabular}

Acceptable limits based on the NCEP performance criteria [10].

Abbreviations: NCEP, National Cholesterol Education Program; SD, standard deviation.

${ }^{*}$ CEQAL (Canada, https://www.ceqal.com/). ${ }^{\dagger}$ Northwest Lipid Metabolism and Diabetes Research Laboratories (https://endocrinology.uw.edu/ research/institutes). ${ }^{*}$ Reference Material Institute for Clinical Chemistry Standards (Japan, http://www.reccs.or.jp/en/). ${ }^{5}$ National Medical Reference Laboratory (Korea, from the second round of 2017; http://www.cdc.go.kr/CDC/eng/). "Health Sciences Authority, Singapore. 'Consensus (average of each test of all participants excluding outlier). 
Reference Laboratory), 또는 싱가포르의 Health Sciences Authority 표준검사실에 의뢰하였다. 중성지방 중에 글리세롤 소거법(glycerol blanking)의 참고값은 총 글리세라이드(total glyceride)에서 유리 글리세롤을 뺀 값으로 하였고, 글리세롤 비소거법(glycerol non-blanking)의 참고값은 총 글리세라이 드 값으로 하였다. 각 참가기관의 종목별 허용기준은 Table 1에 있는 대로 National Cholesterol Education Program (NCEP) 총 오차기준으로 평가하였다. Apolipoprotein A1, apolipoprotein B, lipoprotein (a) 종목은 아직 뚜렷한 참고측 정방법 의뢰가 어려워서 참가기관들의 합의 평균(consensus mean)을 참고값으로 하였다. 또한 각 종목별 허용범위는 Table 1 과 같이 정하였다[10]. 단, 합의 평균 및 표준편차 산 정은 참가기관의 사분위간범위(interquartile range, IQR) 의 1.5배를 초과하여 Q1보다 낮거나 IQR의 1.5배를 초과하여 Q3보다 높은 결과값을 벗어난 것을 이상점(outlier)으로 간주 하여 제거한 후에 산정하였다.

\section{결과}

정확도기반지질검사에 참가하는 기관 수는 첫 해에 164 기관 으로 2016년도 일반화학검사 프로그램 총 콜레스테롤 참가기 관 수 1,366 개 기관의 $12 \%$ 에 불과하였으나 3 년째인 2018 년도 에는 223 기관이 참여하여 약 $15 \%$ 로 증가하였다[11,12]. 참가 기관 수의 증가는 Table 2 와 같았다. 3 년간 NCEP 오차허용범 위 기준으로 볼 때에 총 콜레스테롤, HDL 콜레스테롤, 총 글 리세리드(글리세롤 비소거법)의 참가기관 평균오차는 1-2회 만 NCEP 허용오차를 벗어난 데 비해 중성지방(글리세롤 소
거법), 특히 $\mathrm{LDL}$ 콜레스테롤은 더 여러 차례 $\mathrm{NCEP}$ 허용오 차를 벗어났다(Tables 3,4$)$. 참가기관 중에 10 개 이상의 기 관이 사용한 총 콜레스테롤, $\mathrm{HDL}$ 콜레스테롤, $\mathrm{LDL}$ 콜레스 테롤, 총 글리세리드, 중성지방 시약의 제조사별 오차의 3 개 년 동안의 추이는 Fig. 1부터 Fig. 5에 기술하였다. CAL-1703 검체의 경우에 중성지방이 $277 \mathrm{mg} / \mathrm{dL}$ 로 높은 검체였는 데, $\mathrm{LDL}$ 콜레스테롤의 오차기준을 넘어서는 기관이 많아 평 가에서 제외하였다. Apolipoprotein A1, apolipoprotein B, 및 lipoprotein (a)의 경우에는 참고방법으로 참고값을 구하기 힘 들어 합의 평균을 기초로 각 기관의 오차와 평균오차를 구하였 고 3개년간의 그 추이는 Supplementary Figs. 1-4까지 기술 하였다. 한편, 각 기관별로 Table 1에 기술한 오차허용범위 내 에 들어가는 기관의 비율의 추이는 Fig. 6에 기술하였는데, 총 콜레스테롤 및 중성지방(글리세롤 비소거법)의 경우에는 허용 범위 내에 대부분의 기관이 들었으나. HDL 콜레스테롤은 허 용범위를 벗어나는 기관도 꽤 있었고, 특히 LDL 콜레스테롤 의 경우에는 허용범위 이내의 값을 보고한 기관이 약 $90 \%$ 내 외를 유지하다가 마지막 회차에 허용범위 내에 들어가는 기관 이 $98 \%$ 로 높아졌다.

\section{고찰}

대한임상검사정도관리협회는 혈청의 기질효과(matrix effect)를 최소화하고 교환성(commutability)을 유지하기 위 하여 2016년도부터 정확도기반지질검사 신빙도사업 프로그 램을 시작하였다. 매년 참가기관이 증가하여 3차연도 참여기 관은 1차연도 참여기관에 비해 $13.6 \%-41.8 \%$ 증가하였다. 한

Table 2. Number of participating laboratories for accuracy-based lipids programs of the Korean Association of External Quality Assessment Service from 2016 to 2018

\begin{tabular}{|c|c|c|c|c|c|c|c|}
\hline \multirow{2}{*}{ Variable } & \multicolumn{6}{|c|}{ Year-round } & \multirow{2}{*}{$\begin{array}{c}\text { Increase } \\
(\%)^{*}\end{array}$} \\
\hline & 2016-1st & 2016-2nd & 2017-1st & 2017-2nd & 2018-1st & 2018-2nd & \\
\hline Total cholesterol & 164 & 165 & 169 & 185 & 219 & 223 & 36.0 \\
\hline Low-density lipoprotein cholesterol & 158 & 159 & 164 & 178 & 210 & 214 & 35.4 \\
\hline Triglycerides $^{\dagger}$ & 159 & 163 & 167 & 184 & 217 & 221 & 39.0 \\
\hline Triglycerides (glycerol blanking) & 61 & 62 & 59 & 66 & 83 & 82 & 34.4 \\
\hline Apolipoprotein A1 & 67 & 70 & 77 & 77 & 79 & 77 & 14.9 \\
\hline Apolipoprotein B & 79 & 83 & 93 & 94 & 99 & 98 & 24.1 \\
\hline Lipoprotein (a) & 59 & 59 & 65 & 65 & 68 & 67 & 13.6 \\
\hline
\end{tabular}

*Percent increase in the number of participating laboratories for each item from 2016 to $2018 .{ }^{\dagger}$ The number of participating laboratories for triglycerides, including total glycerides (glycerol non-blanking) and triglycerides (glycerol blanking). 
Journal of LABORATORY MEDICINE and QUALITY ASSURANCE

Jeong-Ho Kim et al • Accuracy-Based Lipid Survey in Korea

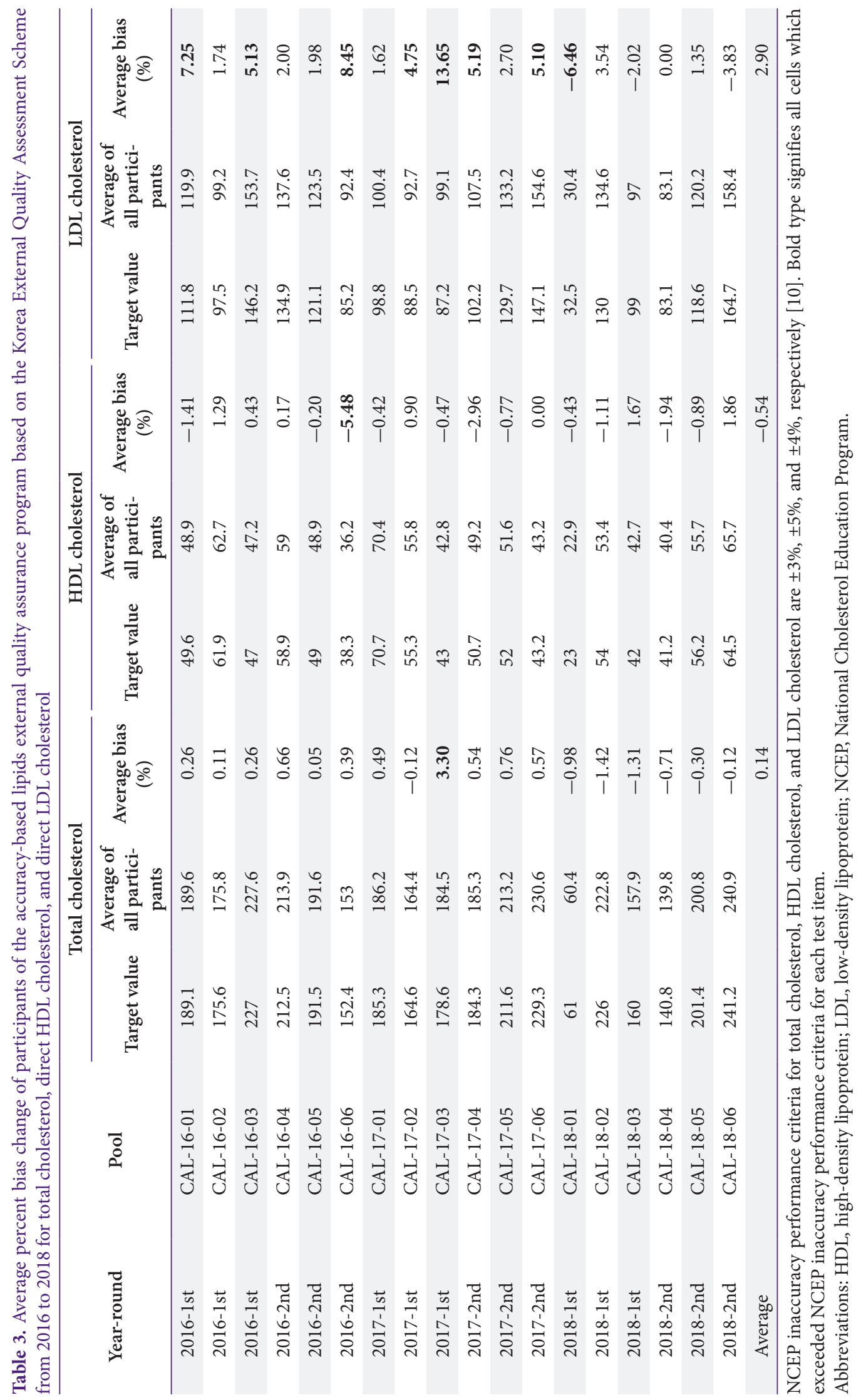


Table 4. Average percent bias change of participants of the accuracy-based lipids external quality assurance program based in Korea External Quality Assessment Scheme from 2016 to 2018 for total glycerides (glycerol non-blanking) and triglycerides (glycerol blanking) assay

\begin{tabular}{|c|c|c|c|c|c|c|c|}
\hline \multirow[b]{2}{*}{ Year-round } & \multirow[b]{2}{*}{ Pool } & \multicolumn{3}{|c|}{ Total glycerides (glycerol non-blanking) } & \multicolumn{3}{|c|}{ Triglycerides (glycerol blanking) } \\
\hline & & Target value & $\begin{array}{c}\text { Average of all } \\
\text { participants }\end{array}$ & $\begin{array}{c}\text { Average bias } \\
(\%)\end{array}$ & Target value & $\begin{array}{c}\text { Average of all } \\
\text { participants }\end{array}$ & $\begin{array}{c}\text { Average bias } \\
(\%)\end{array}$ \\
\hline $2016-1 \mathrm{st}$ & CAL-16-01 & 134.5 & 130.4 & -3.05 & 127.6 & 127.4 & -0.16 \\
\hline $2016-1 \mathrm{st}$ & CAL-16-02 & 69 & 65 & -5.80 & 61.7 & 57.9 & -6.16 \\
\hline 2016-1st & CAL-16-03 & 145.4 & 144.4 & -0.69 & 139.1 & 141.6 & 1.80 \\
\hline 2016-2nd & CAL-16-04 & 84.6 & 83.7 & -1.06 & 72.6 & 70.4 & -3.03 \\
\hline 2016-2nd & CAL-16-05 & 100.1 & 97 & -3.10 & 91.3 & 87.7 & -3.94 \\
\hline 2016-2nd & CAL-16-06 & 154.8 & 158.9 & 2.65 & 143.9 & 150.1 & 4.31 \\
\hline 2017-1st & CAL-17-01 & 76.6 & 74.9 & -2.22 & 67.3 & 63.7 & -5.35 \\
\hline 2017-1st & CAL-17-02 & 86.2 & 84.8 & -1.62 & 76.9 & 74.8 & -2.73 \\
\hline 2017-1st & CAL-17-03 & 277.1 & 279.1 & 0.72 & 260.7 & 265.9 & 1.99 \\
\hline 2017-2nd & CAL-17-04 & 180.9 & 182.2 & 0.72 & 174.5 & 177.7 & 1.83 \\
\hline 2017-2nd & CAL-17-05 & 149.8 & 150.9 & 0.73 & 145.3 & 148.6 & 2.27 \\
\hline 2017-2nd & CAL-17-06 & 178.9 & 181.5 & 1.45 & 172.9 & 177.7 & 2.78 \\
\hline 2018-1st & CAL-18-01 & 35.05 & 34.4 & -1.85 & 32.5 & 28.4 & -12.62 \\
\hline 2018-1st & CAL-18-02 & 178.81 & 178.5 & -0.17 & 130 & 134.6 & 3.54 \\
\hline 2018-1st & CAL-18-03 & 98.92 & 98.7 & -0.22 & 99 & 97 & -2.02 \\
\hline 2018-2nd & CAL-18-04 & 92.9 & 91.7 & -1.29 & 86.4 & 86 & -0.46 \\
\hline 2018-2nd & CAL-18-05 & 137.8 & 139.1 & 0.94 & 129.5 & 132.8 & 2.55 \\
\hline 2018-2nd & CAL-18-06 & 63.6 & 60.1 & -5.50 & 54.8 & 50.2 & -8.39 \\
\hline Average & & & & -1.08 & & & -1.32 \\
\hline
\end{tabular}

NCEP inaccuracy performance criteria for triglycerides was $\pm 5 \%$ [10]. Bold type signifies all cells which exceeded NCEP inaccuracy performance criteria for each test item.

Abbreviation: NCEP, National Cholesterol Education Program.

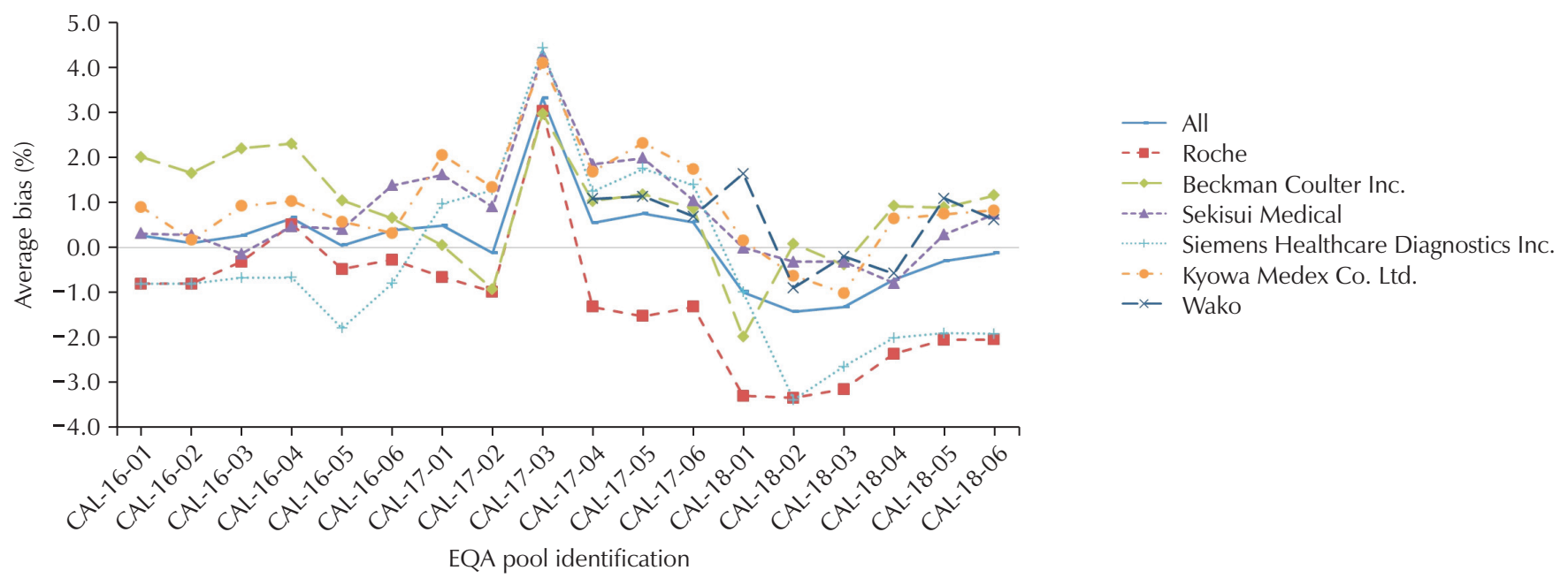

Fig. 1. Average percent bias change for total cholesterol of each manufacturer in the accuracy-based lipids EQA program (2016-2018). Abbreviation: EQA, external quality assessment. The instruments were from the following companies: Roche Diagnostics (Mannheim, Germany); Beckman Coulter Inc. (Brea, CA, USA); Sekisui Medical Co. Ltd. (Tokyo, Japan); Siemens Healthcare Diagnostics Inc. (Erlangen, Germany); Kyowa Medex Co. Ltd. (Tokyo, Japan); and Fujifilm Wako Pure Chemical Corp. (Osaka, Japan). 


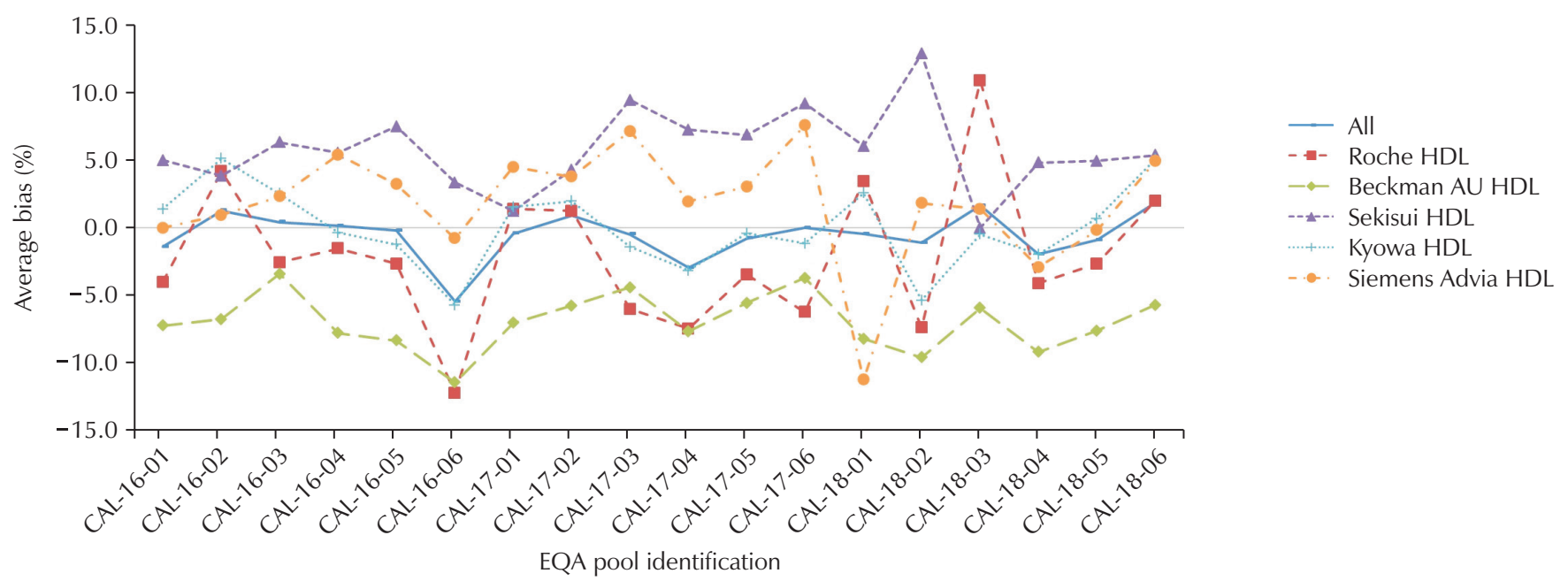

Fig. 2. Average percent bias change in the direct HDL cholesterol assay of each manufacturer in the accuracy-based lipid EQA program (2016-2018). Abbreviations: HDL, high-density lipoprotein; EQA, external quality assessment. The instruments were from the following companies: Roche Diagnostics (Mannheim, Germany); Beckman Coulter Inc. (Brea, CA, USA); Sekisui Medical Co. Ltd. (Tokyo, Japan); Kyowa Medex Co. Ltd. (Tokyo, Japan); and Siemens Healthcare Diagnostics Inc. (Erlangen, Germany).

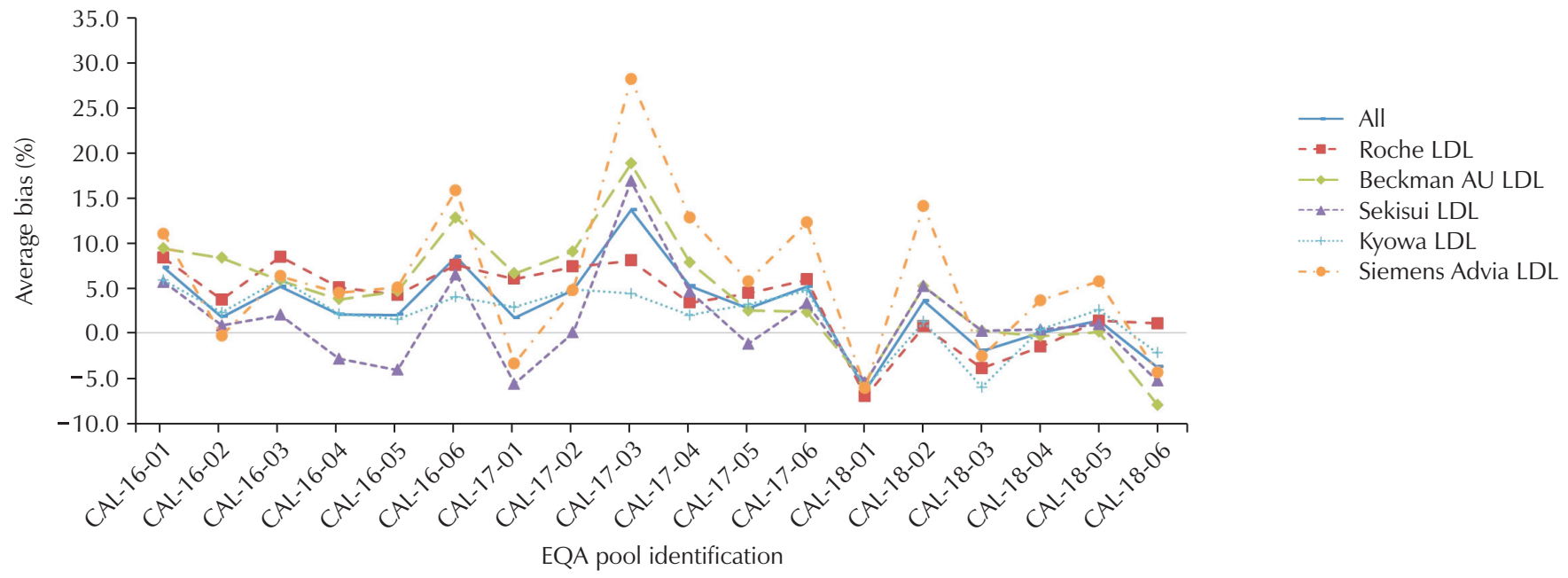

Fig. 3. Average percent bias change in the direct LDL cholesterol assay of each manufacturer in the accuracy-based lipid EQA program (2016-2018). We excluded the CAL-17-03 pool, as it may not be suitable for the evaluation of LDL cholesterol in the external quality assurance program. Abbreviations: LDL, low-density lipoprotein; EQA, external quality assessment. The instruments were from the following companies: Roche Diagnostics (Mannheim, Germany); Beckman Coulter Inc. (Brea, CA, USA); Sekisui Medical Co. Ltd. (Tokyo, Japan); Kyowa Medex Co. Ltd. (Tokyo, Japan); and Siemens Healthcare Diagnostics Inc. (Erlangen, Germany).

편, 3차연도에는 총 콜레스테롤, $\mathrm{HDL}$ 콜레스테롤, $\mathrm{LDL}$ 콜 레스테롤, 중성지방(글리세롤 비소거법 및 글리세롤 소거법) 모두에서 참가기관들의 평균 \%오차는 대부분 $\mathrm{NCEP}$ 검사별 수행 정확도 기준범위 내에 들어 왔으나, 3 년간 연 2회 각 회 차마다 3 가지 농도의 총 18 개의 $\mathrm{CFS}$ 검체를 종합적으로 평 가하였을 때, 총 콜레스테롤 및 $\mathrm{HDL}$ 콜레스테롤은 각 1 회,
$\mathrm{LDL}$ 콜레스테롤은 8회, 중성지방(글리세롤 비소거법)은 2 회, 중성지방(글리세롤 소거법)은 4회에서 $\mathrm{NCEP}$ 허용기준 을 벗어났다. 한편, 총 콜레스테롤의 경우에 제조사 간의 정확 도에 약간의 차이가 있었는데 Roche사(Roche Diagnostics, Mannheim, Germany)의 경우에 $1 \%-2 \%$ 의 음성오차를 보이 는데, 이는 시약 및 칼리브레이터 제조 시 참고방법을 isotope 


\section{Journal of LABORATORY MEDICINE and QUALITY ASSURANCE}

Jeong-Ho Kim et al • Accuracy-Based Lipid Survey in Korea

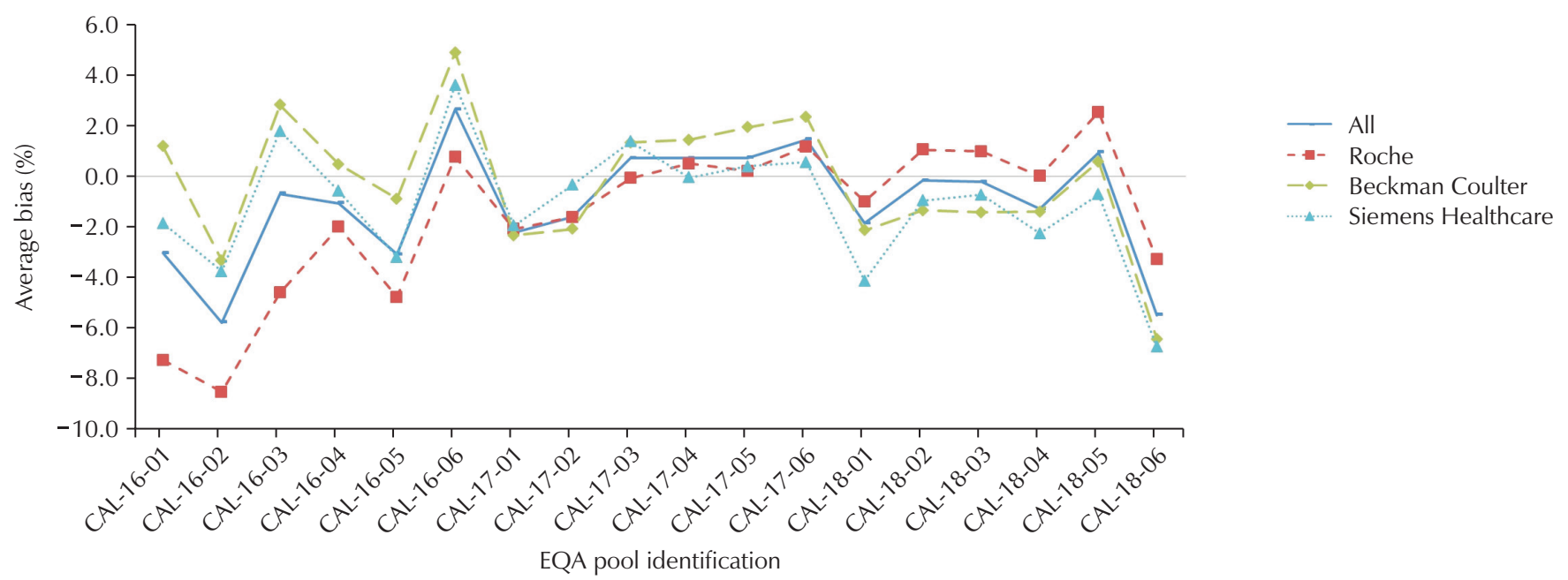

Fig. 4. Average percent bias change in the total glycerides (glycerol non-blanking) assay of each manufacturer in the accuracybased lipids EQA program (2016-2018). Abbreviation: EQA, external quality assessment. The instruments were from the following companies: Roche Diagnostics (Mannheim, Germany); Beckman Coulter Inc. (Brea, CA, USA); and Siemens Healthcare Diagnostics Inc. (Erlangen, Germany).

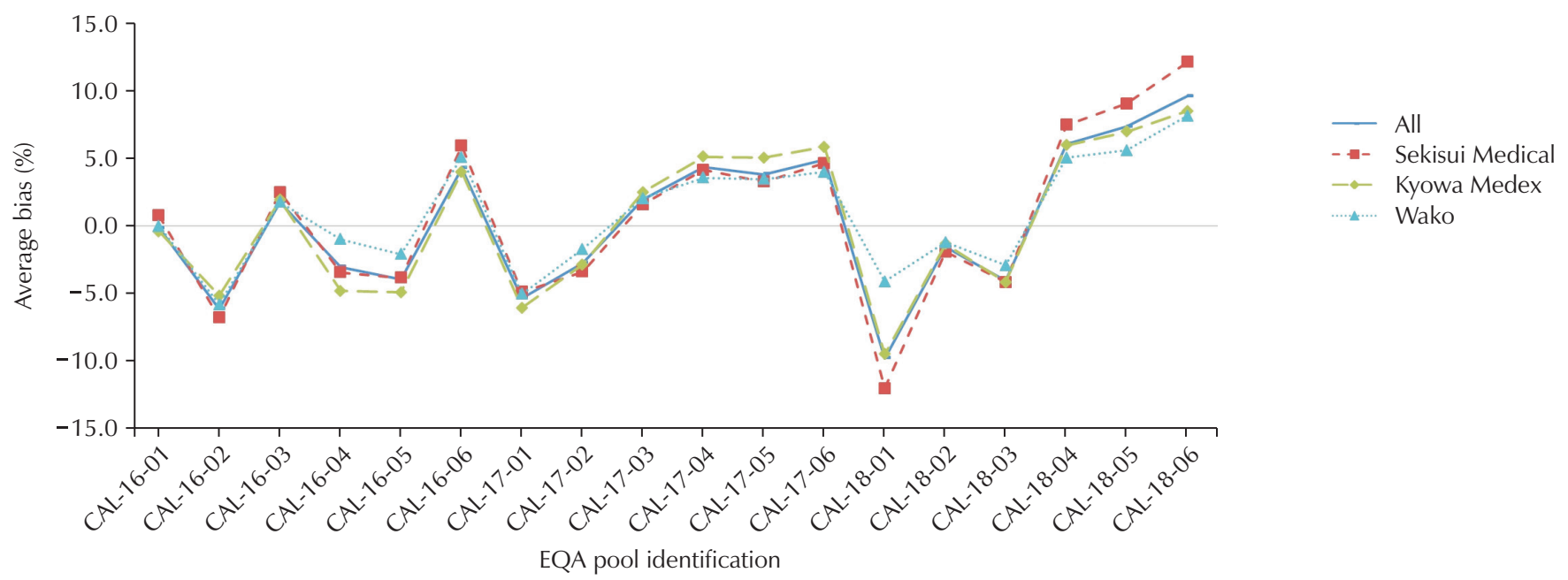

Fig. 5. Average percent bias change in the triglycerides (glycerol blanking) assay of each manufacturer in the accuracy-based lipids EQA program (2016-2018). Abbreviation: EQA, external quality assessment. The instruments were from the following companies: Sekisui Medical Co. Ltd. (Tokyo, Japan); Kyowa Medex Co. Ltd. (Tokyo, Japan); and Fujifilm Wako Pure Chemical Corp. (Osaka, Japan).

dilution gas chromatography-mass spectrometry (ID-GC$\mathrm{MS}$ )법을 기준으로 하기 때문으로 보인다(Fig. 1). 대한임상 검사정도관리협회 프로그램에서는 비록 ID-GC-MS법에 비 해 비특이적인 양성오차를 보이지만, 미국, 일본 등지에서 많 이 쓰이는 Abell Kendall법을 참고검사법으로 사용하였다. 아 직 미국, 일본 등에서는 Abell Kendall법의 정확도 문제를 인 지하고 있음에도 불구하고 과거부터 역학연구에서 많이 사용
되었던 Abell Kendall법을 참고방법으로 고수하고 있는 실정 이다. HDL 콜레스테롤의 경우에 Sekisui사(Sekisui Medical Co. Ltd., Tokyo, Japan)는 양성오차를, Beckman Coulter 사(Beckman Coulter Inc., Brea, CA, USA)는 음성오차를 보이는 경향이 있었다(Fig. 2). LDL 콜레스테롤의 경우에는 전체적으로 양성오차를 보이는 경향이 있었고 특히 Siemens 제품(Siemens Healthcare Diagnostics Inc., Erlangen, 


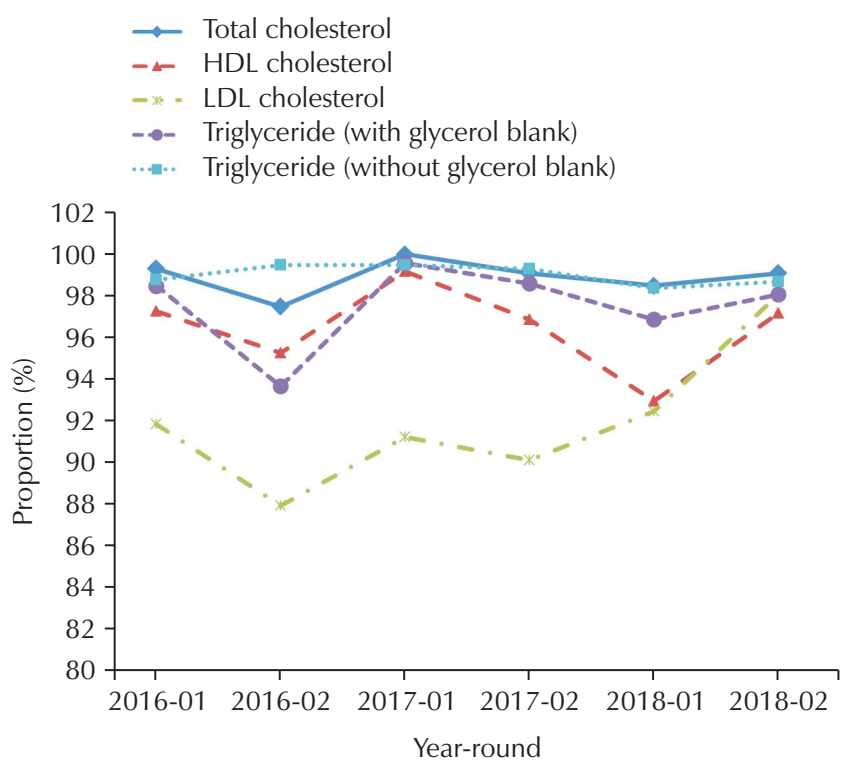

Fig. 6. Change in the proportion of participating laboratories with an acceptable performance in each test in the accuracybased lipids proficiency testing from 2016 to 2018 in the Korean External Quality Assurance Scheme. We excluded the CAL-17-03 pool among three pools of the 2017-01 round, as it may not be suitable for the evaluation of LDL cholesterol performance in the external quality assurance program. Abbreviations: HDL, high-density lipoprotein; LDL, low-density lipoprotein.

Germany)의 양성오차가 컸다(Fig. 3). 그러나 LDL 콜레스테 롤의 경우에 냉동 혈청을 사용하는 경우에 정확도 평가에 문제 가 있고 신선 혈청이나 혈장을 비교평가에 추천하기 때문에 결 론을 내리기 힘든 항목이라 하겠다[13]. 특히 CAL-17-03 검 체의 경우에 중성지방이 $277 \mathrm{mg} / \mathrm{dL}$ 로 높고 각 기관별 LDL 오차범위를 벗어난 기관이 매우 많이 발생하였기에, 외부정 도관리물질로는 부적합다고 판정하여 평가에 사용하지 않았 다. 이 검체를 $\mathrm{LDL}$ 아형분석을 해 보니 초저밀도지단백(very low-density lipoprotein, VLDL)이 22.2\%이었고 VLDL 비 율이 높을수록 LDL 콜레스테롤 직접법의 평균오차를 증가시 키는 것으로 추정되었다. 그러나 VLDL은 오히려 $\mathrm{LDL}$ 콜레 스테롤의 음성오차를 일으킨다는 문헌과는 서로 배치되는 결 과로서, 측정에 사용되는 시약에 따라 간섭을 일으키는 기전 이 달라질 수 있을 것으로 추정되며 추가연구가 필요할 것으 로 생각되었다[14]. 중성지방의 경우에는 대부분 가수분해하 여 글리세롤을 측정하는 방법이 많이 사용되고 있다. 그러나 혈액에는 유리 글리세롤이 약 $5 \%$ 정도 소량 존재하며 경우에 따라 글리세롤을 약제로 사용하는 경우에는 그 양이 많을 수
있어 글리세롤 소거법(glycerol blanking)이 정확한 방법이라 할 수 있고 일본에서는 대부분의 임상검사실에서 이 방법을 사 용하지만 전 세계적으로는 글리세롤 비소거법(glycerol nonblaking)을 더 많이 사용한다[15,16]. 우리나라에서는 글리세 롤 소거법을 사용하는 기관이 참여기관 중에 $35 \%-38 \%$ 정도 를 차지하였다(Table 2). 이렇게 두 가지 방법이 사용되다 보 니 전국적인 연구나 빅 데이터 연구에 혼동을 일으키는 문제가 있다. 또한 외부정도관리사업을 하는 입장에서 각 참여기관이 글리세롤 소거법을 쓰는지 비소거법을 쓰는지 명확한 확인이 필요하다. 그리고 본 프로그램과 같이 정확도기반지질검사의 경우에 총 글리세리드(total glycerides)뿐만 아니라 유리 글리 세롤을 참고방법을 이용하여 별도로 측정해야 하는 문제가 발 생한다[17-19]. 한편, apolipoprotein A1, apolipoprotein B, lipoprotein (a)와 같은 아포단백은 현재 참고방법을 개발하는 단계이고 참고검사실 의뢰가 어려운 면이 있어 합의 평균을 기 준으로 정확도를 평가하였다[20,21] (Supplementary Figs. $1-3)$.

결론적으로, 이 정확도기반지질검사는 기질효과를 최소화하 여 교환성이 있는 냉동혈청을 사용하여 우리나라 임상검사실 의 지질검사의 정확도를 평가하고 있으며, 제조사별로 통계를 내어 정확도 항상에 기여하고 있다고 생각한다.

\section{감사의 글}

저자들은 이 정확도기반지질검사 사업과 보고서 작성까지 많은 도움을 주신 충남대학교 의과대학 진단검사의학교실 권 계철 교수님, 임진숙 교수님과 건국대학교병원 김하나 교수님, 그리고 질병관리본부 조찬익 선생님 등 여러분들께 감사를 드 린다.

\section{REFERENCES}

1. Da Silva PM, Duarte JS, von Hafe P, Gil V, de Oliveira JN, de Sousa G. Standardization of laboratory and lipid profile evaluation: a call for action with a special focus in 2016 ESC/EAS dyslipidaemia guidelines: full report. Atheroscler Suppl 2018;31:e1-e12.

2. Hoerger TJ, Wittenborn JS, Young W. A cost-benefit analysis of lipid standardization in the United States. Prev Chronic Dis 2011;8:A136.

3. Klee GG, Killeen AA. College of American Pathologists 2003 fresh frozen serum proficiency testing studies. Arch 
Pathol Lab Med 2005;129:292-3.

4. Miller WG, Jones GR, Horowitz GL, Weykamp C. Proficiency testing/external quality assessment: current challenges and future directions. Clin Chem 2011;57:1670-80.

5. Ross JW, Miller WG, Myers GL, Praestgaard J. The accuracy of laboratory measurements in clinical chemistry: a study of 11 routine chemistry analytes in the College of American Pathologists Chemistry Survey with fresh frozen serum, definitive methods, and reference methods. Arch Pathol Lab Med 1998;122:587-608.

6. College of American Pathologists. 2008 ABL-B participant summary. http://webapps.cap.org/apps/docs/committees/ chemistry/accuracy_based_lipid_survey.pdf (Accessed September 23, 2019).

7. Jeong TD, Lee HA, Lee K, Yun YM. Accuracy-based proficiency testing of creatinine measurement: 7 years' experience in Korea. J Lab Med Qual Assur 2019;41:13-23.

8. Clinical and Laboratory Standards Institute. Preparation and validation of commutable frozen human serum pools as secondary reference materials for cholesterol measurement procedures; approved guideline: NCCLS document C37-A. Wayne (PA): Clinical and Laboratory Standards Institute, 1999.

9. Centers for Disease Control and Prevention. Cholesterol reference method laboratory network (CRMLN): analytical services provided by CRMLN member laboratories. https://www.cdc.gov/labstandards/pdf/crmln/CRMLN_ Analytical_Services_List-508.pdf (Accessed September 23, 2019).

10. Warnick GR, Kimberly MM, Waymack PP, Leary ET, Myers GL. Standardization of measurements for cholesterol, triglycerides, and major lipoproteins. Lab Med 2008;39:481-90.

11. Lee YW. Annual report on the external quality assessment scheme for general chemistry in Korea (2017). J Lab Med Qual Assur 2018;40:113-27.

12. Lee YW, Jeon BR, Kim JG, Jun SH, Yun YM, Chun S, et al. Annual report on the external quality assessment scheme for routine clinical chemistry in Korea (2016). J Lab Med Qual Assur 2017;39:61-75.
13. Miller WG, Myers GL, Sakurabayashi I, Bachmann LM, Caudill SP, Dziekonski A, et al. Seven direct methods for measuring HDL and LDL cholesterol compared with ultracentrifugation reference measurement procedures. Clin Chem 2010;56:977-86.

14. Wagner AM, Zapico E, Bonet R, Perez A, OrdonezLlanos J. The effect of VLDL particles on the accuracy of a direct LDL-cholesterol method in type 2 diabetic patients. Clin Biochem 2003;36:177-83.

15. Nakamura $M$, Iso $H$, Kitamura $A$, Imano $H$, Noda $H$, Kiyama M, et al. Comparison between the triglycerides standardization of routine methods used in Japan and the chromotropic acid reference measurement procedure used by the CDC Lipid Standardization Programme. Ann Clin Biochem 2016;53:632-9.

16. Cole TG. Glycerol blanking in triglyceride assays: is it necessary? Clin Chem 1990;36:1267-8.

17. Li H, Dong J, Chen W, Wang S, Guo H, Man Y, et al. Measurement of serum total glycerides and free glycerol by high-performance liquid chromatography. J Lipid Res 2006;47:2089-96.

18. Edwards SH, Stribling SL, Pyatt SD, Kimberly MM. Reference measurement procedure for total glycerides by isotope dilution GC-MS. Clin Chem 2012;58:768-76.

19. Chen Y, Teo HL, Liu Q, Lee TK. Developing a reference measurement procedure for free glycerol in human serum by two-step gas chromatography-isotope dilution mass spectrometry. Clin Biochem 2015;48:897-903.

20. Tate JR, Berg K, Couderc R, Dati F, Kostner GM, Marcovina SM, et al. International Federation of Clinical Chemistry and Laboratory Medicine (IFCC) Standardization Project for the Measurement of Lipoprotein(a): phase 2: selection and properties of a proposed secondary reference material for lipoprotein(a). Clin Chem Lab Med 1999;37:949-58.

21. Van den Broek I, Romijn FP, Nouta J, van der Laarse A, Drijfhout JW, Smit NP, et al. Automated multiplex LCMS/MS assay for quantifying serum apolipoproteins A-I, B, C-I, C-II, C-III, and E with qualitative apolipoprotein E phenotyping. Clin Chem 2016;62:188-97. 